\title{
PENGARUH MODEL PEMBERDAYAAN BERPIKIR MELALUI PERTANYAAN (PBMP) TERHADAP KEMAMPUAN BERPIKIR KRITIS SISWA DI SMP NEGERI 10 KUPANG TAHUN AJARAN 2019/2020
}

\section{(THE EFFECT OF THINKING EMPOWERMENT MODEL THROUGH QUESTIONS (PBMP) ON STUDENT'S CRITICAL THINKING ABILITY AT 10 KUPANG STATE MIDDLE SCHOOL FOR THE ACADEMIC YEAR 2019/2020)}

\author{
Margareta Mone 1), Theodora S.N. Manu ${ }^{2)}$, Agus Maramba Meha ${ }^{3)}$ \\ ${ }^{123}$ Program Studi Pendidikan Biologi, Fakultas Keguruan dan IImu Pendidikan Universitas \\ Kristen Artha Wacana Kupang - NTT
}

Corresponding author : rithamone@gmail.com

\begin{abstract}
ABSTRAK
Permasalahan utama dalam penelitian ini adalah rendahnya kemampuan berpikir kritis siswa kelas VIII SMP Negeri 10 Kupang. Tujuan penelitian ini adalah untuk mengetahui pengaruh model PBMP (pemberdayaan berpikir melalui pertanyaan) terhadap kemampuan berpikir kritis siswa. Metode yang digunakan yaitu quasi eksperimental dengan desain Posttest Only Control Design. Populasi seluruh siswa kelas VIII berjumlah 327 siswa dan Sampel kelas VIII ${ }^{H}$ dan VIII ${ }^{J}$ dengan jumlah 64 siswa.Teknik pengambilan sampel yang digunakan adalah simple random sampling. Pengumpulan data dilakukan dengan tes kemampuan berpikir krits dan bantuan rubrik kemampuan berpikir kritis. Data kemampuan berpikir kritis siswa diperoleh dari hasil analisis uji-t, dengan bantuan softwere SPSS versi 22. Berdasarkan hasil uji hipotesis diperoleh nilai t 15,492 dengan signifikan 0,000 atau kurang dari 0,5 hal tersebut menunjukkan bahwa terdapat pengaruh model PBMP terhadap kemampuan berpikir kritis siswa memberi penjelasan sederhana memiliki persentase sebesar $41,09 \%$ dan memberi penjelasan lebih lanjut memiliki persentase sebesar 38,eksperimen. Hasil penelitian menunjukkan bahwa kemampuan berpikir kritis pada kelas eksperimen lebih tinggi yaitu pada indikator memberi penjelasan sederhana memiliki persentase sebesar $43,43 \%$, membangun keterampilan dasar memiliki persentase sebesar 40,52\%, menyimpulkan memiliki 95\% dibandingkan dengan kemampuan berpikir kritis pada kelas kontrol karena pada proses pembelajaran pada kelas eksperimen mengunakan model PBMP sedangkan pada kelas kontrol hanya menggunakan metode ceramah. Hal ini dapat membuktikan bahwa adanya pengaruh model PBMP (Pemberdayaan Berpikir Melalui Pertanyaan) terhadap kemampuan berpikir kritis.
\end{abstract}

Kata kunci : Model pembelajaran, pemberdayaan berpikir, berpikir kritis, siswa.

\section{ABSTRACK}

The main problem in this research is the low critical thinking ability of class VIII students of SMP Negeri 10 Kupang. The purpose of this study was to determine the effect of the PBMP model (thinking empowerment through questions) on students' critical thinking skills. The method used is quasi-experimental with Posttest Only Control Design. The population of all students in class VIII is 327 students and the samples for class VIIIH and VIIIJ are 64 students. The sampling technique used is simple random sampling. Data was collected by means of a critical thinking ability test and the help of a critical thinking ability rubric. Data on students' critical thinking skills were obtained from the results of $t$-test analysis, with the help of SPSS version 22 software. Based on the results of hypothesis testing, the t-value was 15,492 with a significance of 0.000 or less than 0.5, this indicates that there is an influence of the PBMP model on students' critical thinking skills. giving a simple explanation has a percentage of $41.09 \%$ and giving a further explanation has a percentage of 38, an experiment. The results showed that the critical thinking ability in the experimental class was higher, namely the indicator giving a simple explanation had a percentage of $43.43 \%$, building basic skills had a percentage of $40.52 \%$, concluded that it had $95 \%$ compared to the critical thinking ability in the control class because in the learning process in the experimental class using the PBMP model while the control class only uses the lecture method. This can prove that there is an effect of the PBMP (Thinking Empowerment Through Questions) model on critical thinking skills. 


\section{PENDAHULUAN}

Pendidikan adalah proses perubahan tingkah laku dari yang tidak tahu menjadi yang lebih tahu. Menurut undang-undang No. 20 Tahun 2003 tentang sistem pendidikan nasional, pendidikan adalah usaha sadar dan terencana untuk mewujudkan suasana belajar dan proses pembelajaran agar peserta didik secara aktif mengembangkan potensi dirinya untuk memiliki kekuatan spiritual keagamaan, pengendalian diri, kepribadian, kecerdasan akhlak mulia serta keterampilan yang perlukan dirinya, masyarakat, bangsa, dan negara. Melalui pendidikan dapat dihasilkan sumber daya manusia yang berkualitas serta siap untuk secara kreatif dan aktif bersaing dalam menghadapi berbagai perkembangan dan tantangan yang terjadi. Salah satu mata pelajaran yang penting diberikan kepada siswa dalam proses pendidikan adalah biologi.

Depdiknas (2003) menjelaskan bahwa melalui pembelajaran biologi, siswa diharapkan dapat menjadi pribadi yang senantiasa menjaga alam dengan penuh rasa tanggung jawab, siswa juga diproses untuk mampu menguasai dan mengaplikasikan berbagai konsep-konsep. Dengan kemampuan ini siswa mampu menghadapi berbagai masalah yang ditemuinya dalam kehidupan sehari-hari serta untuk menumbuhkan karakter yang baik. Keterampilan dan kemampuan siswa yang harus terus diberdayakan dalam kegiatan pembelajaran agar tujuan pendidikan khususnya tujuan pembelajaran biologi dapat tercapai adalah kemampuan berpikir kritis. Berpikir kritis merupakan sebuah proses yang bermuara pada penarikan kesimpulan tentang apa yang harus kita percayai dan tindakan apa yang akan kita lakukan. Bukan untuk mencari jawaban semata, tetapi yang terlebih utama adalah mempertanyakan jawaban, fakta, atau informasi yang ada.

Kemampuan berpikir kritis telah menjadi hal yang sangat diperhatikan dalam pengembangan berpikir siswa. Di era globalisasi ini, semua informasi dengan sangat mudah masuk ke dalam diri setiap individu siswa. Mudah masuknya segala informasi, membuat siswa harus berpikir secara kritis untuk menyaring informasi-informasi tersebut. Karena tidak semua di dalam informasi global tersebut baik, melainkan ada yang bersifat buruk. Mereka harus mampu membedakan antara alasan yang baik dan buruk serta membedakan kebenaran dari kebohongan (Johnson, 2007).

Namun pada kenyataannya, pemberdayaan kemampuan berpikir kritis belumlah dilakukan secara efektif. Pembelajaran biologi masih menekankan pada pengembangan kemampuan menghafal konsep, prinsip, dan istilah biologi (Ekoningtyas, 2013). Berdasarkan hasil observasi di SMP Negeri 10 Kota Kupang pada kelas VIII dengan materi tentang sistem pencernaan pada manusia menunjukan bahwa kemampuan berpikir kritis belum dilaksanakan dalam kegiatan pembelajaran biologi dengan efektif, selain itu hasil belajar siswa pun rendah dan hal itu tentu saja ada kaitannya dengan tidak diberdayakannya kemampuan berpikir kritis siswa.

Rendahnya upaya pemberdayaan kemampuan berpikir kritis dapat dilihat dari masih dipertahankannya kebiasaan mengajar ceramah. Pembelajaran biologi di SMP sebenarnya sudah mengembangkan berbagai metode untuk melatih siswa agar bersikap kritis, namun terkadang kurang optimal karena guru banyak menggunakan metode ceramah. Sebab pengembangan kemampuan berpikir kritis siswa dalam pembelajaran biologi sangat penting, guna menghadapi kondisi dunia yang semakin berkembang. Kondisi yang ada akan menuntut siswa untuk dapat merespon masalah secara kritis dan dapat mengembangkan berbagai metode untuk melatih siswa dalam pemecahan masalah.

Salah satu model pembelajaran yang mampu memberdayakan kemampuan berpikir kritis siswa adalah model pembelajaran permberdayaan berpikir melalui pertanyaan (PBMP). Model PBMP ini mampu memberdayakan siswa untuk menjawab pertanyaan-pertanyaan yang tersusun secara sistematis. Pembelajaran berpola PBMP tidak berlangsung secara informatif. Model pembelajaran tersebut mampu memicu anak untuk bepikir sehingga apabila model PBMP diterapkan secara terus-menerus diyakini mampu meningkatkan kemampuan berpikir dan anak mampu mengatur proses berpikirnya (Haerulla, 2012). Sutikno (2002) \& Zubaidah (2001) juga telah membuktikan adanya peningkatan penalaran pada siswa dengan menggunakan model PBMP. Salah satu kelebihan dari pembelajaran berpola PBMP ini dapat diterapkan dengan menggunakan banyak metode. 
Alasan model PBMP diterapkan karena model ini belum pernah diterapkan untuk mengatasi kesulitan belajar siswa pada pembelajaran IPA. Padahal pembelajaran berpola PBMP mampu memberdayakan proses berpikir siswa melalui lembar PBMP. Pengalaman lokal material ini bertujuan untuk memberdayakan segala sesuatu yang ada di lingkunagn sekitar siswa sebagai media untuk belajar, sehingga meskipun sarana prasarana yang disediakan sekolah sangat kurang memadai, siswa dapat melaksanakan kegiatan pembelajaran dengan maksimal. Adapun tujuan penelitian ini adalah untuk mengetahui pengaruh model PBMP (pemberdayaan berpikir melalui pertanyaan) terhadap kemampuan berpikir kritis siswa Di SMP Negeri 10 Kota Kupang Tahun ajaran 2019/2020.

\section{METODE PENELITIAN}

\section{Metode Penelitian}

Metode penelitian yang digunakan dalam penelitian ini adalah penelitian eksperimen, dengan jenis penelitian eksperimen semu.

\section{Desain Penelitian}

Desain penelitian yang digunakan dalam penelitan ini adalah Posttest-Only Control Design. Data kemampuan berpikir kritis diperoleh setelah perlakuan model pembelajaran di kelas eksperimen dan kelas kontrol. Desain penelitian digambarkan sebagai berikut.

Tabel 1. Posttest-Only Control Design

\begin{tabular}{ccc}
\hline Kelompok & Perlakuan & Posttest \\
\hline $\mathrm{E}$ & $\mathrm{X}$ & $\mathrm{O} 2$ \\
\hline $\mathrm{K}$ & - & $\mathrm{O} 4$ \\
\hline
\end{tabular}

Keterangan:

E : Kelompok eksperimen

K : Kelompok kontrol

O2 : Posttest kelompok eksperimen

O4 : Posttest kelompok kontrol

$\mathrm{X}$ : Perlakuan model PBMP

\section{Lokasi dan Waktu Penelitian}

Penelitian ini telah dilaksanakan di kelas VIII SMP Negeri 10 Kota Kupang yang beralamat di Kelurahan Lasiana Kecamatan Kelapa Lima Kabupaten Kota Kupang, penelitian ini telah dilaksanakan pada semester ganjil tahun ajaran 2019/2020.

\section{Populasi dan Sampel}

Populasi dalam penelitian ini adalah seluruh siswa kelas VIII SMP Negeri 10 Kota Kupang yang berjumlah 327 orang. Sampel yang digunakan dalam penelitian ini adalah dua kelas yaitu kelas VIII $\mathrm{H}$ yang berjumlah 32 orang sebagai kelas eksperimen dan kelas VIII $\mathrm{J}$ yang berjumlah 32 orang sebagai kelas kontrol. Pengambilan sampel menggunakan teknik simple Random Sampling.

\section{Teknik Pengumpulan Data}

Teknik pengumpulan data dalam penelitian ini adalah tes. Tes yang digunakan adalah tes kemampuan berpikir kritis dalam bentuk essay test. Tes essay merupakan pertanyaan yang menuntut siswa menjawabnya dalam bentuk menguraikan, menjelaskan, mendiskusikan, membandingkan, memberi alasan, dan bentuk lain yang sejenis dengan tuntutan pertanyaan dengan menggunakan kata-kata dan bahasa sendiri. Tes esay pada penelitian ini digunakan untuk mengukur kemampuan berpikir kritis siswa pada mata pelajaran IPA yang terdiri dari memberi penjelasan sederhana, membangun keterampilan dasar, menyimpulkan dan memberi penjelasan lanjut: Penilaian terhadap hasil jawaban siswa terhadap soal tes essay dilakukan dengan bantuan rubrik kemampuan berpikir kritis yang dikembangkan oleh Zubaidah (2005). 


\section{Teknik Analisis Data}

Analisis data merupakan cara untuk menentukan menyusun dan mengolah data yang terkumpul, sehingga menghasilkan suatu kesimpulan yang dapat dipertanggung jawabkan kebenarannya. Analisis yang akan dilakukan dalam penelitian ini adalah menggunakan teknik Uji-t dengan bantuan softwere SPSS versi 22. Prasyarat analisis dilakukan, terlebih dahulu melalui pengujian normalitas dan homogenitas data.

\section{HASIL DAN PEMBAHASAN}

\section{Deskripsi Data Kelas Eksperimen}

Data yang dikumpulkan dalam penelitian ini berupa data hasil kemampuan berpikir kritis siswa yang diperoleh dari posttest. Adapun distribusi frekuensi hasil posttest kelas $\mathrm{VIII}^{\mathrm{H}}$ dapat dilihat pada Tabel 2.

Tabel 2. Distribusi Frekuensi Kelas VIII ${ }^{\mathrm{H}}$

\begin{tabular}{cccc}
\hline No & Rentang Nilai & F & Presentase \\
\hline $\mathbf{1}$ & $77-79$ & 6 & $18,75 \%$ \\
\hline $\mathbf{2}$ & $80-82$ & 16 & $50 \%$ \\
\hline $\mathbf{3}$ & $83-85$ & 5 & $15,625 \%$ \\
\hline $\mathbf{4}$ & $86-88$ & 2 & $6,25 \%$ \\
\hline $\mathbf{5}$ & $89-91$ & 2 & $6,25 \%$ \\
\hline $\mathbf{6}$ & $92-94$ & 1 & $3,125 \%$ \\
\hline \multicolumn{2}{r}{ Jumlah skor $(\Sigma)$} & $\mathbf{3 2}$ & $\mathbf{1 0 0} \%$ \\
\hline
\end{tabular}

Berdasarkan distribusi frekuensi hasil posttest, maka dapat digambarkan dalam bentuk grafik yang dapat dilihat pada Gambar 1 .

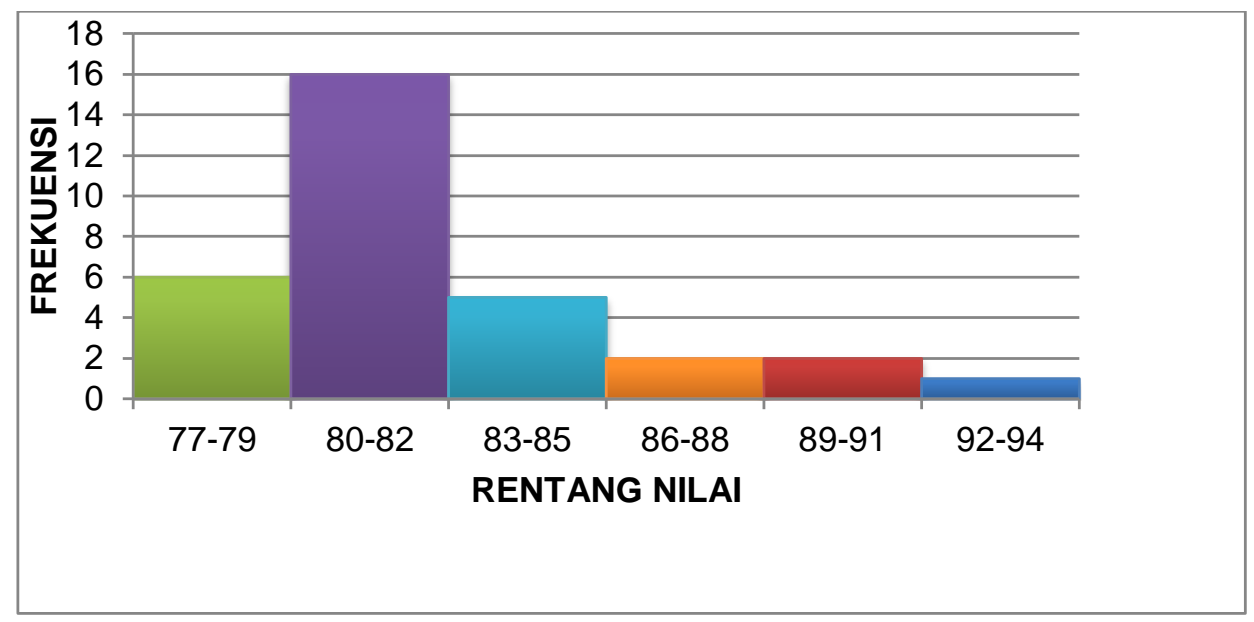

Gambar 1. Grafik Hasil Posttest Kelas VIII

Tabel dan diagram posttest siswa kelas VIII ${ }^{\mathrm{H}}$ SMP Negeri 10 Kupang menunjukkan bahwa siswa memperoleh nilai dari 77-79 terdapat 6 siswa dengan persentase 18,75\%. Dari nilai 80-82 terdapat 16 siswa dengan persentase $50 \%$. Dari nilai 83-85 terdapat 5 siswa dengan persentase 15,625\%. Dari nilai 86-88 terdapat 2 siswa dengan persentase 6,25\%. Dari nilai 89-91 terdapat 2 siswa dengan persentase 6,25\%. Dari 92-94 terdapat 1 siswa dengan persentase $3,125 \%$. 


\section{Deskripsi Nilai Rata-Rata Kelas Eksperimen}

Deskripsi nilai rata-rata kemampuan berpikir kritis siswa pada kelas eksperimen sesuai indikator berpikir kritis dapat dilihat pada Gambar 2.

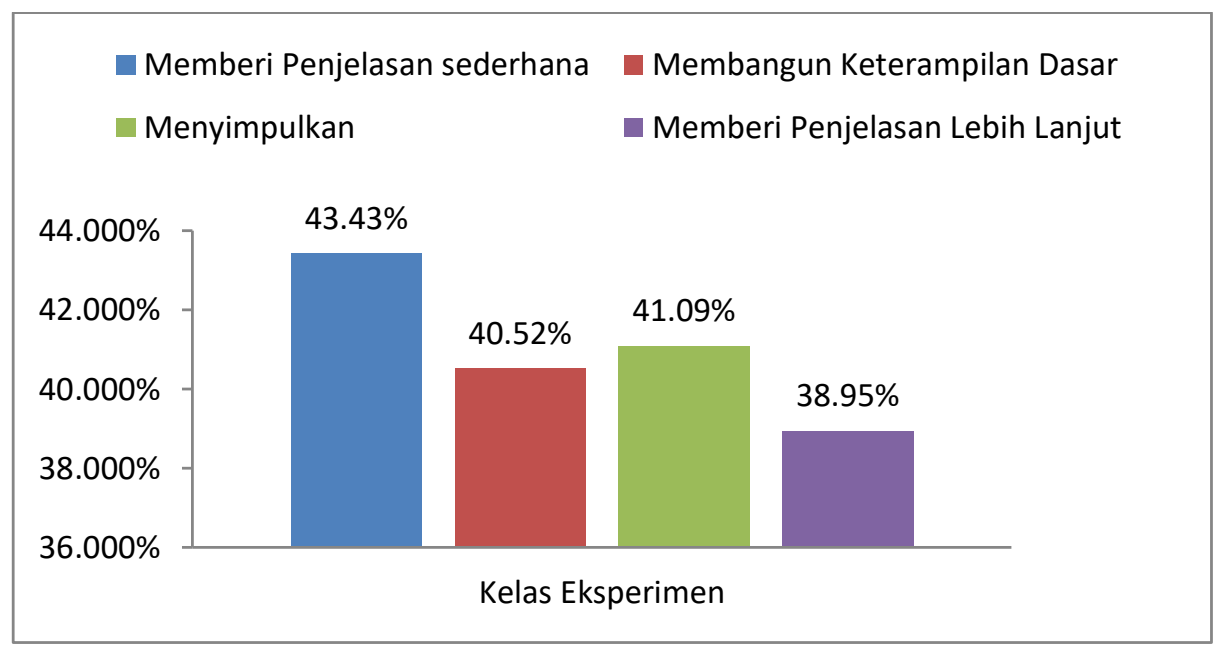

Gambar 2. Persentase Kelas Eksperimen

Berdasarkan Gambar 3 menunjukkan persentase indikator kemampuan berpikir kritis dari siswa berdasarkan jumlah skor pada kelas ekperimen yakni pada indikator memberi penjelasan sederhana memiliki persentase sebesar $43,43 \%$, membangun keterampilan dasar memiliki persentase sebesar $40,52 \%$, menyimpulkan memiliki persentase sebesar $41,09 \%$ dan memberi penjelasan lebih lanjut memiliki persentase sebesar 38,95\%.

\section{Deskripsi Data Kelas Kontrol}

Data yang dikumpulkan dalam penelitian ini berupa data hasil kemampuan berpikir kritis siswa yang diperoleh dari posttest. Adapun distribusi frekuensi hasil posttest kelas VIIIj dapat dilihat pada Tabel 2.

Tabel 3. Distribusi Frekuensi Kelas VIII

\begin{tabular}{llcc}
\hline No & Rentang Nilai & F & Presentase \\
\hline 1 & $54-57$ & 5 & $15,625 \%$ \\
\hline 2 & $58-61$ & 10 & $31,25 \%$ \\
\hline 3 & $62-65$ & 7 & $21,875 \%$ \\
\hline 4 & $66-69$ & 7 & $21,875 \%$ \\
\hline 5 & $70-73$ & 0 & $0 \%$ \\
\hline 6 & $74-77$ & 3 & $9,375 \%$ \\
\hline & Jumlah skor $(\Sigma)$ & $\mathbf{3 2}$ & $\mathbf{1 0 0} \%$ \\
\hline
\end{tabular}

Berdasarkan distribusi frekuensi hasil posttest, maka dapat digambarkan dalam bentuk grafik yang dapat dilihat pada Gambar 3. 


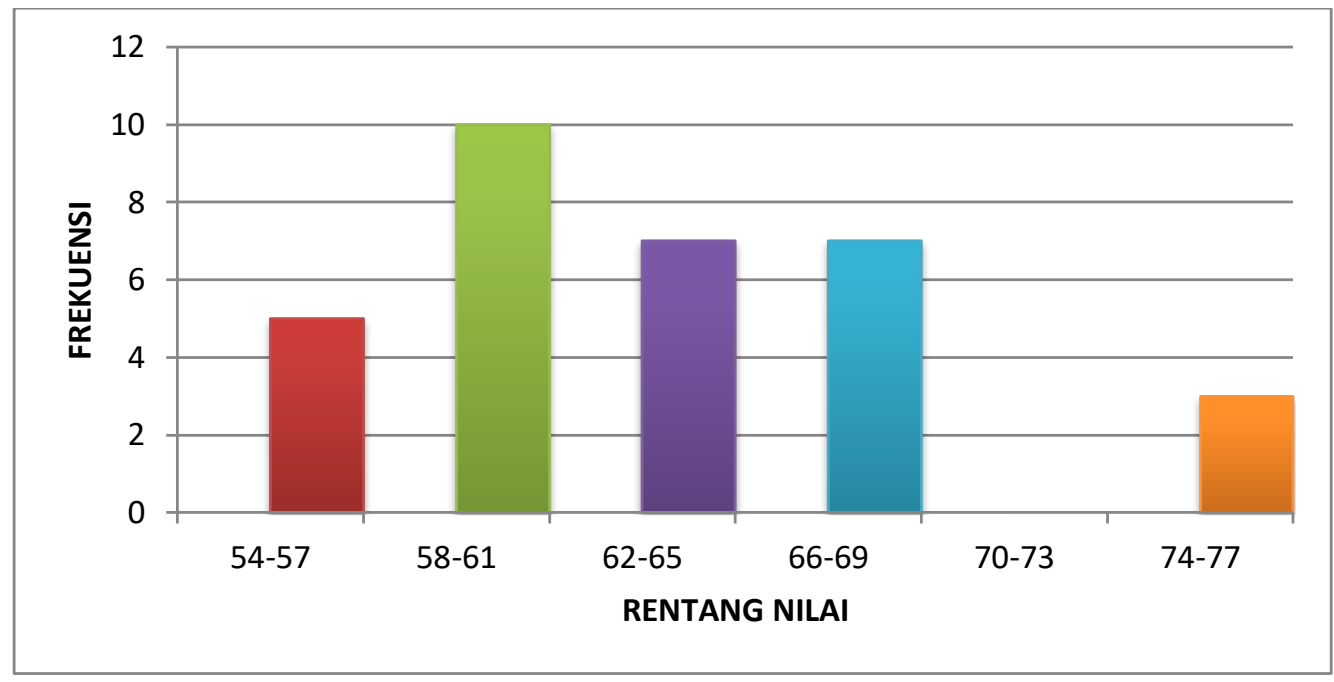

Gambar 3. Grafik Hasil Posttest Kelas VIIIj

Tabel dan diagram posstestsiswa kelas VIII ${ }^{\mathrm{S}}$ SMP Negeri 10 Kupang menunjukan bahwa siswa memperoleh nilai dari 55-57 terdapat 5 siswa dengan persentase 15,625\%. Dari nilai $58-61$ terdapat 10 siswa dengan persentase $31,25 \%$. Dari nilai $62-65$ terdapat 7 siswa dengan persentase $21,875 \%$. Dari nilai 66-69 terdapat 7 siswa dengan persentase $21,875 \%$. Dari nilai $70-73$ tidak terdapat siswa dengan persentase $0 \%$. Dari nilai 74-77 terdapat 3 siswa dengan persentase $9.375 \%$.

\section{Deskripsi Nilai Rata-Rata Kelas Kontrol}

Deskripsi nilai rata-rata kemampuan berpikir kritis siswa pada kelas kontrol sesuai indikator berpikir kritis dapat dilihat pada Gambar 4.

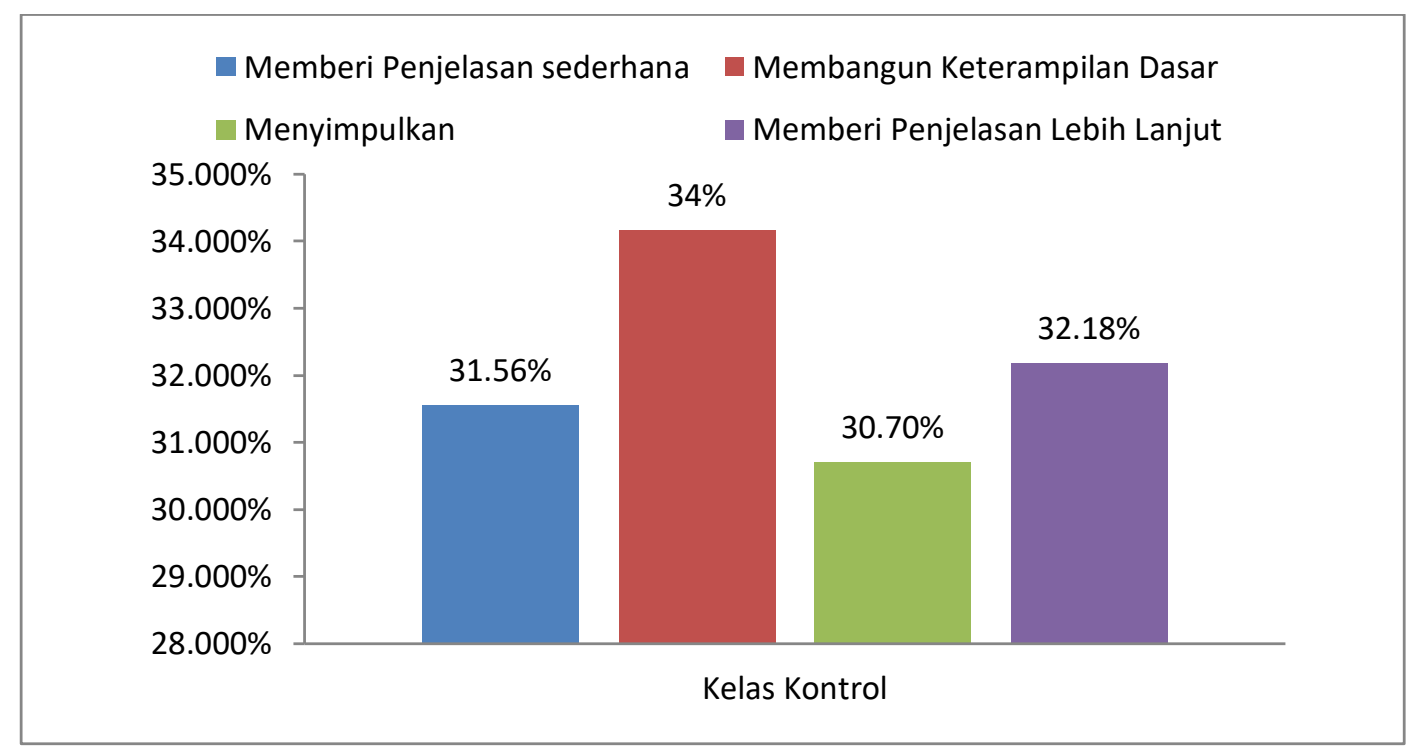

Gambar 4. Persentase Kelas Kontrol

Berdasarkan Gambar 4 menunjukkan persentase indikator kemampuan berpikir kritis dari siswa berdasarkan jumlah skor pada kelas kontrol yakni pada indikator memberi penjelasan sederhana memiliki persentase sebesar 31,56\%, membangun keterampilan dasar memiliki persentase sebesar $34 \%$, menyimpulkan memiliki persentase sebesar $30,70 \%$ dan memberi penjelasan lebih lanjut memiliki persentase sebesar $31,18 \%$. 


\section{Hasil Uji Hipotesis}

test.

Uji hipotesis dapat digunakan dalam penelitian ini menggunakan uji Independent Sample t-

Hipotesis yang diuji adalah:

$\mathrm{H}_{0}$ : Tidak terdapat pengaruh penggunaan model PBMP terhadap kemampuan berpikir kritis siswa

$\mathrm{H}_{1}$ : Terdapat pengaruh penggunaan model PBMP terhadap kemampuan berpikir kritis siswa

Dalam analisis tersebut, kriteria yang digunakan untuk menerima hipotesis nilai $\left(\mathrm{H}_{0}\right)$ dan hipotesis alternatif $\left(\mathrm{H}_{1}\right)$ yaitu :

1) Jika angka signifikan $>0,05$ maka $\mathrm{H}_{0}$ diterima dan $\mathrm{H}_{1}$ ditolak

2) Jika angka signifikan $<0,05$ maka $\mathrm{H}_{0}$ ditolak dan $\mathrm{H}_{1}$ diterima

Tabel 4 Hasil analisis uji t kemampuan berpikir kritis

\begin{tabular}{|c|c|c|c|c|c|c|c|c|c|}
\hline \multicolumn{10}{|c|}{ Independent Samples t-test } \\
\hline & \multicolumn{4}{|c|}{$\begin{array}{l}\text { Levene'sT } \\
\text { estfor } \\
\text { Equality of } \\
\text { Variances }\end{array}$} & \multicolumn{5}{|c|}{ t-test for Equality of Means } \\
\hline & \multirow[b]{2}{*}{$F$} & \multirow[b]{2}{*}{ Sig. } & \multirow[b]{2}{*}{$T$} & \multirow[b]{2}{*}{$D f$} & \multirow{2}{*}{$\begin{array}{l}\text { Sig. } \\
\text { (2- } \\
\text { taile } \\
\text { d) }\end{array}$} & \multirow{2}{*}{$\begin{array}{c}\text { Mean } \\
\text { Differenc } \\
e\end{array}$} & \multirow{2}{*}{$\begin{array}{c}\text { Std. } \\
\text { Error } \\
\text { Differen } \\
\text { ce }\end{array}$} & \multicolumn{2}{|c|}{$\begin{array}{l}\text { 95\% Confidence } \\
\text { Interval of the } \\
\text { Difference }\end{array}$} \\
\hline & & & & & & & & Lower & Upper \\
\hline $\begin{array}{l}\text { Equal } \\
\text { variances } \\
\text { assumed }\end{array}$ & 3.463 & $\begin{array}{c}.06 \\
8\end{array}$ & 15.492 & 62 & .000 & $\begin{array}{c}18.5781 \\
3 \\
\end{array}$ & 1.19918 & 16.18100 & $\begin{array}{c}20.9752 \\
5\end{array}$ \\
\hline $\begin{array}{l}\text { Equal } \\
\text { variances } \\
\text { not } \\
\text { assumed }\end{array}$ & & & 15.492 & 5.052 & .000 & $\begin{array}{c}18.5781 \\
3\end{array}$ & 1.19918 & 16.17686 & $\begin{array}{c}20.9793 \\
9\end{array}$ \\
\hline
\end{tabular}

Berdasarkan Tabel 4. di atas, diperoleh nilai sig. (2-tailed) sebesar 0,000. Karena nilai sig. lebih kecil dari 0,05 sehingga $\mathrm{H}_{1}$ diterima dan $\mathrm{H}_{0}$ ditolak atau terdapat pengaruh model PBMP terhadap kemampuan berpikir kritis siswa.

\section{Pembahasan}

Berdasarkan hasil uji hipotesis menggunakan rumus uji t diperoleh hasil analisis data pada taraf signifikan Sig. (2-tailed) $=0.000<0,05$. Hal ini berarti adanya pengaruh model PBMP terhadap kemampuan berpikir kritis siswa. Berdasarkan hasil penelitian, dapat diketahui bahwa kemampuan berpikir kritis siswa pada kelas eksperimen terlihat lebih tinggi. Hal ini dilihat pada saat pembelajaran di kelas eksperimen mengunakan model PBMP. Dalam pelaksanaan pembelajaran dengan mengunakan model PBMP menuntut siswa untuk saling berinteraksi dalam menjawab pertanyaan yang disediakan pada LKS PBMP. Dengan adanya interaksi ini membuat siswa lebih aktif dalam mencari informasi untuk menjawab setiap pertanyaan.Dimana pada bagian "sediakan" dari LKS PBMP, siswa menyiapkan alat tulis serta buku yang diperlukan untuk mengerjakan LKS.Pada bagian "lakukan" siswa berdiskusi dalam kelompok untuk mengerjakan LKS. Sedangkan pada bagian "renungkan" siswa sangat aktif dalam kelompok untuk menjawab pertanyaan yang ada dalam lembar LKS serta siswa juga mencari informasi dari berbagai sumber dan bertanya pada peneliti 
apabila kurang memahami informasi yang diperoleh sehingga siswa terlibat lebih aktif selama proses pembelajaran.

Pada bagian "pikirkan" siswa mampu menyampaikan informasi yang diperoleh. Sedangkan pada bagian "evaluasi", siswa mampu menjawab pertanyaan yang diberikan oleh peneliti serta mampu mengemukakan pendapatnya sendiri.Sehingga pemahaman terhadap materi yang diajarkan pun dapat dicerna dengan baik oleh siswa. Hal ini sejalan dengan penelitian yang dilakukan oleh Imkari (2012) yang menyatakan bahwa model PBMP dapat meningkatkan kemampuan berpikir kritis. Sejalan dengan itu Zubaidah (2005) menjelaskan bahwa kemampuan berpikir kritis dapat dikembangkan melalui berbagai aktivitas, diantaranya dengan membuat pertanyaan.

Pembelajaran dengan mengunakan model PBMP nampaknya memberikan hasil positif terhadap kemampuan berpikir siswa yang sebelumnya rendah. Kemampuan berpikir ini sangat menentukan keberhasilan siswa dalam belajarnya.Selain itu, melalui sintak-sintak pembelajaran PBMP, siswa berkesempatan untuk mengembangkan hubungan antar kelompok, menghargai perbedaan, dan meningkatkan harga diri mereka, sehingga mendorong tumbuhnya kesadaran saling membelajarkan antar siswa.

Berbeda dengan pembelajaran yang berlangsung pada kelas kontrol yang tidak menggunakan model pembelajaran PBMP atau tidak diberikan perlakuan, kemampuan berpikir kritis siswa rendah. Hal ini dikarenakan dalam pelaksanaan pembelajaran pada kelas kontrol menggunakan metode ceramah, sehingga siswa hanya mendengarkan penjelasan dari peneliti. Sehingga dalam pelaksanaan pembelajaran siswa kurang aktif, karena siswa jenuh dan bosan mendengarkan penjelasan dari peneliti serta siswa merasa takut ketika akan bertanya kepada peneliti, siswa sibuk sendiri di belakang dan tidak memperhatikan apa yang diajarkan peneliti, hal ini dikarenakan cara penyampaian materi pembelajaran belum dapat menimbulkan suasana yang menyenangkan serta tidak ada interaksi baik antara sesama siswa maupun dengan guru. Dibandingkan dengan kelas eksperimen yang lebih aktif dalam proses pembelajaran yang diberikan perlakuan dengan model pembelajaran PBMP.

Selain itu juga pada kelas kontrol proses pembelajarannya membuat siswa kurang aktif di kelas, hal ini dikarenakan proses pembelajarannya berpusat pada guru sebagai pemberi informasi sehingga pembelajaran terkesan membosankan akibatnya kemampuan berpikir kritis siswa di kelas kontrol rendah. Hal ini terlihat dari kesiapan siswa yang kurang siap untuk belajar dan sulit memahami konsep, hanya beberapa siswa yang antusias dan aktif mengikuti proses pembelajaran sedangkan yang lainnya tidak memperhatikan tetapi sibuk dengan kegiatannya sendiri seperti bercerita dengan teman atau pun mengganggu teman lainnya meskipun sudah ditegur oleh guru. Siswa jenuh dan bosan dalam mengikuti proses pembelajaran, siswa hanya pasif mendengarkan materi yang disampaikan oleh peneliti. Sehingga siswa pada kelas kontrol nilai akhirnya pun masih terlihat rendah, terlihat pada saat peneliti memberikan test, siswa tidak menjawab soal dengan baik. Sehingga pembelajaran pada kelas kontrol tidak mampu meningkatkankemampuan berpikir kritis siswa.

Dari hasil penerapan Model PBMP, terlihat bahwa adanya peningkatkan yang terlihat pada kelas eksperimen, dimana pada indikator memberi penjelasan sederhana mendapatkan persentase sebesar $43,43 \%$, alasan bahwa pada aspek ini memiliki persentase yang lebih tinggi merupakan tingkat aspek paling mudah. Dimana siswa lebih mudah menganalisis argumen dan menjelaskan konsep dengan benar dan jelas. Pada indikator membangun keterampilan dasar mendapatkan persentase sebesar 40,52\%, memiliki persentase seperti itu karena siswa lebih mudah menjelaskan konsep dibanding mempertimbangkan kredibilitas. Dimana pada lembar PBMP terdapat serangkaian pertanyaan yang membantu siswa untuk melatih proses berpikirnya baik dalam menjelaskan konsep serta dapat menyelidiki informasi dan pengalaman tertentu.

Pada indikator menyimpulkan mendapatkan persentase sebesar $41,09 \%$, karena pada aspek ini siswa dapat membuat keputusan dan mempertimbangkan hasilnya. Dimana pada saat proses pembelajaran berlangsung baik pada tahap renungkan, pikirkan, maupun evaluasi siswa dapat menyimpulkan materi yang telah dijelaskan sebelumnya. Hal ini sejalan dengan pendapat 
Yunarti (2009) bahwa salah satu cara untuk meningkatkan kemampuan berpikir siswa adalah melalui pertanyaan.

Sedangkan pada indikator memberi penjelasan lebih lanjut mendapatkan persentase sebesar $38,95 \%$ karena siswa dapat mengidentifikasi istilah-istilah dalam materi yang diajarkan dengan benar serta dapat mempertimbangkannya. Hal ini sesuai dengan kelebihan dari model PBMP yaitu siswa dapat mempertimbangkan serta membedakan sesuatu yamg baik dan tidak baik maupun yang benar dan yang tidak benar. Indikator kemampuan berpikir kritis yang diukur pada penelitian ini hanya 4 indikator yakni memberi penjelasan sederhana, membangun keterampilan dasar, menyimpulkan dan memberi penjelasan lebih lanjut dikarenakan pada indikator kelima sudah termasuk di indikator memberi penjelasan sederhana dan indikator menyimpulkan. Dimana pada indikator memberi penjelasan sederhana pada saat guru bertanya dan siswa menjawab pertanyaan yang diberikan oleh guru maka terjadi interaksi antara guru dengan siswa sedangkan pada indikator menyimpulkan siswa diberi kesempatan untuk membuat keputusan dan menarik sebuah kesimpulan dan mempertimbangkan untuk menentukan hasil dari pertimbangannya.

Selain itu perbedaan ini juga dapat dilihat dari proses pembelajaran yaitu pada kelas eksperimen yang diajarkan dengan model pembelajaran PBMP terdapat perubahan pada kemampuan berpikir kritis siswa baik itu aspek memberikan penjelasan sederhana, membangun keterampilan dasar, menyimpulkan, memberi penjelasan lebih lanjut, ditandai dengan keaktifan siswa yaitu mencari informasi dari berbagai sumber untuk menjawab pertanyaan-pertanyaan yang diberikan serta mendiskusikan dengan teman kelompoknya dan siswa juga terlihat lebih semangat saat proses pembelajaran berlangsung. Sedangkan pada kelas kontrol yang diajarkan dengan metode ceramah, kemampuan berpikir kritis siswa terlihat rendah baik dari aspek memberikan penjelasan sederhana, membangun keterampilan dasar, menyimpulkan serta memberi penjelasan lebih lanjut, hal ini disebabkan karena saat proses pembelajarn berlangsung siswa hanya mendengar penjelasan dari guru. Selain itu juga cara penyampaian materi pembelajaran belum dapat menimbulkan suasana yang menyenangkan serta tidak ada interaksi yang aktif antara sesama siswa maupun dengan guru.

Hal ini dikarenakan kemampuan berpikir kritis siswa pada kelas yang menggunakan model PBMP berbeda dengan kelas yang menggunakan metode ceramah. Hal ini dapat dilihat dari skor nilai posttest siswa kelas eksperimen yang menggunakan model PBMP lebih tinggi dibandingkan skor nilai posttest siswa pada kelas kontrol yang menggunakan metode ceramah. Perbedaan ini terjadi karena model PBMP memiliki kelebihan yaitu mampu melatih siswa berpikir kritis dan imajinatif, menggunakan logika, menganalisis fakta-fakta dan melahirkan ide-ide baru, sehingga siswa dapat membedakan mana yang berpikir baik dan tidak baik, mana yang benar dan tidak benar.

\section{KESIMPULAN}

Berdasarkan hasil penelitian dan pembahasan dapat disimpulkan bahwa ada pengaruh penggunaan model pembelajaran PBMP terhadap kemampuan berpikir kritis siswa. Hal ini dibuktikan dengan hasil uji hipotesis menggunakan rumus uji t dengan hasil analisis data pada perhitungan Independent Samples Test menunjukan nilai signifikan Equal variances assumed mempunyai taraf signifikan Sig. (2-tailed) $=0.000$ yang artinya $<0,05$. Hal ini berarti terdapat pengaruh penggunaan model pembelajaran PBMP terhadap kemampuan berpikir kritis siswa di SMP Negeri 10 Kupang Tahun Ajaran 2019/2020.

\section{DAFTAR PUSTAKA}

Depdiknas. 2003. Standar Kompetensi Mata Pelajaran Biologi Sekolah Menengah Atas dan Madrasah Aliyah. Jakarta: Depdiknas

Ekoningtyas. M. 2013. Pengaruh Pembelajaran Think-Pair-Share dipadu Pola Pemberdayaan Berpikir melalui Pertanyaan terhadap Keterampilan Metakognitif, Berpikir Kreatif, Pemahaman Konsep IPA dan Retensinya serta Sikap Sosial Siswa. Malang: Pascasarjana Universitas Negeri Malang 
Haerullah, A. 2012. Potensi Pembelajaran Berpola Pemberdayaan Berpikir Melalui Pertanyaan (PBMP) Dipadu Think Pair Share (TPS) dalam Upaya Memberdayakan Keterampilan Berpikir Kritis Siswa Pada Sekolah Multietnis. Jurnal Bioedukasi. Vol 1 (1).

Imkari, S. 2012. Pengaruh Model Pembelajran TPS dan PBMP terhadap Kemampuan Berikir Kritis, Hasil Belajar Kognitif dan Retensi Mahasiswa. Universitas Negeri Malang.

Johnson, E. 2007. Contextual Teaching and Learning, terjemahan Ibnu Setiawan. Bandung: MLC

Sugiyono. 2014. Metode Penelitian Pendidikan (Pendekatan Kuantitatif, Kualitatif, dan R\&D). Alfabeta: Bandung.

Sutikno. 2002. Pemberdayaan Penalaran Siswa SLTPN 2 Malang Melalui Pembelajaran IPABiologi. Makalah disajikan dalam seminar sehari Pemberdayaan Penalaran dengan Tema Penyiapan Generasi yang Berkualitas melalui pengembangan penalaran Siswa SLTP di SLTPN 2 Malang

Yunarti,T. 2009. Fungsi dan Pentingnya Pertanyaan dalam Pembelajaran. Seminar nasional matematika dan pendidikan matematika jurusan pedidikan matematika Universitas Lampung. (Online), (http://eprints. uny.ac.id/7023 /1/output.pdf). Diakses pada tangal 15 Oktober 2019.

Zubaidah, S. 2001. Implementasi Pembelajaran IPA Biologi dengan PBMP (Pemberdayaan Berpikir Melalui Pertanyaan) Makalah disampaikan pada Pelatihan dan Lokakarya PBMP (Pemberdayaan Berpikir Melalui Pertanyaan) di Universitas Negeri Malang.31 Agustus-1 September 2001.

Zubaidah, S. 2005. Pemberdayaan Berpikir Melalui Pertanyaan. (Online), (http:// jurnal. edu/penelitian-pendidikan/edition/244/vol-13.-no:-2-oktober-2012).Diakses padatanggal 10 Januari 2019. 